\title{
Land-Cover Trends of the Southern California Mountains Ecoregion
}

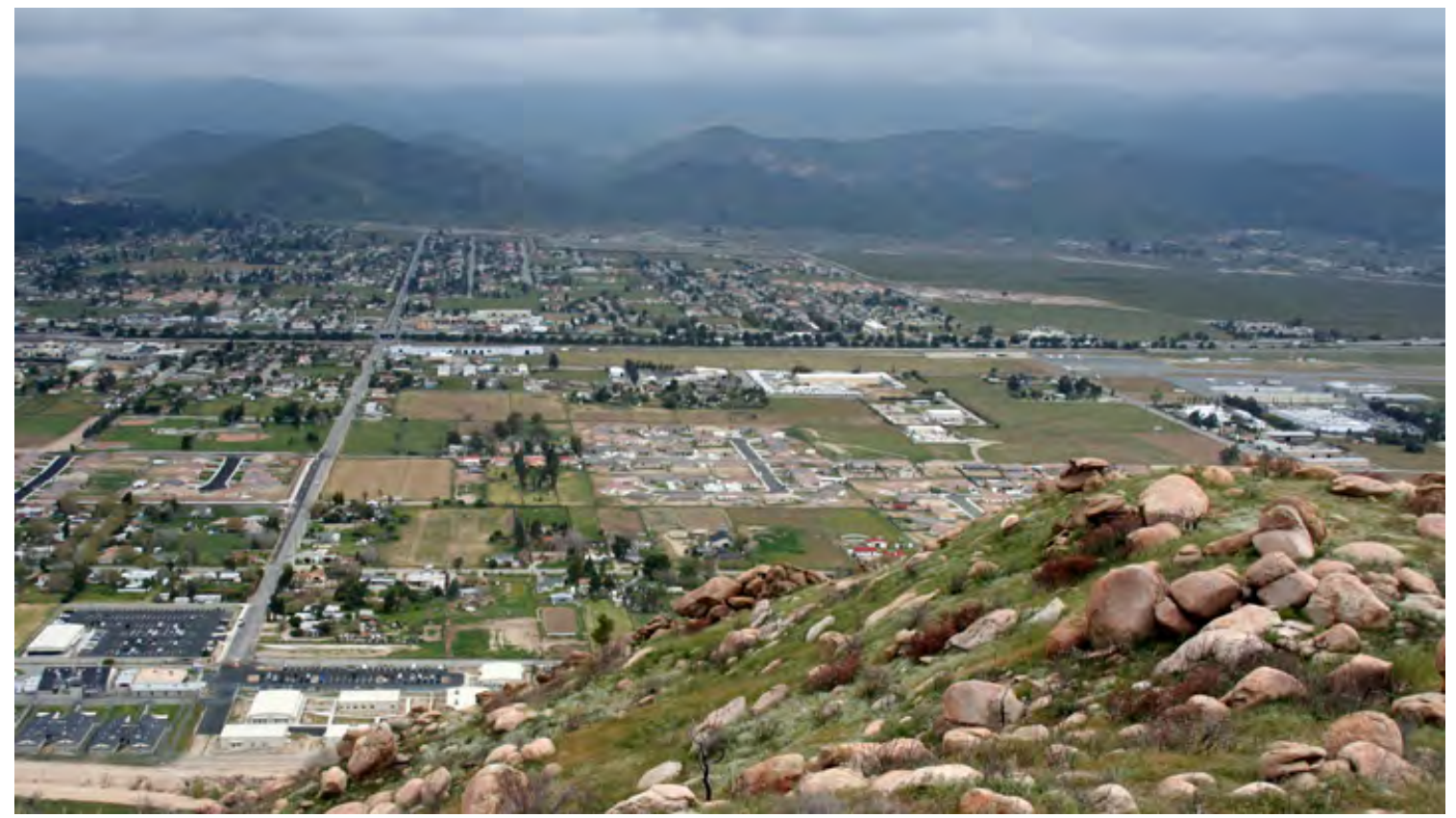

Scientific Investigations Report 2007-5235 


\section{U.S. Department of the Interior DIRK KEMPTHORNE, Secretary}

\section{U.S. Geological Survey \\ Mark D. Myers, Director}

\section{U.S. Geological Survey, Reston, Virginia: 2007}

This report and any updates to it are available at: http://pubs.usgs.gov/sir/2007/5235/

For product and ordering information: World Wide Web: http://www.usgs.gov/pubprod

Telephone: 1-888-ASK-USGS

For more information on the USGS--the Federal source for science about the Earth, its natural and living resources, natural hazards, and the environment:

World Wide Web: http://www.usgs.gov

Telephone: 1-888-ASK-USGS

Any use of trade, product, or firm names is for descriptive purposes only and does not imply endorsement by the U.S. Government.

Although this report is in the public domain, permission must be secured from the individual copyright owners to reproduce any copyrighted materials contained within this report.

Suggested citation:

Soulard, C.E., Raumann, C.G., and Wilson, T.S., 2007, Land-Cover Trends of the Southern California Mountains Ecoregion: U.S. Geological Survey Scientific Investigation Report 2007-5235.

Manuscript approved for publication, September 10, 2007

Text edited by James W. Hendley II

Layout by Luis Menoyo

FRONT COVER

Photograph of development in the foothills of Banning, Calif. 


\section{Foreword}

The U.S. Geological Survey (USGS) Land Cover Trends research project is focused on understanding the amounts, rates, trends, causes, and implications of contemporary land-use and land-cover change in the United States. This project is supported by the USGS Geographic Analysis and Monitoring Program in cooperation with the U.S. Environmental Protection Agency and the National Aeronautics and Space Administration (NASA).

Land-use and land-cover (LU/LC) change is a pervasive process that modifies landscape characteristics and affects a broad range of socioeconomic, biologic, and hydrologic systems. Understanding the impacts and feedbacks of LU/LC change on environmental systems requires an understanding of the rates, patterns, and driving forces of past, present, and future LU/LC change. The objectives of the Land Cover Trends project are to (1) determine and describe the amount, rates, and trends of contemporary LU/LC change by ecoregion for the period 1973-2001 for the conterminous United States, (2) document the causes, driving forces, and implications of change, and (3) synthesize individual ecoregion results into a national assessment of LU/LC change.

The Land Cover Trends research team includes USGS staff from the National Center for Earth Resources Observation and Science (EROS), Rocky Mountain Geographic Science Center, Eastern Geographic Science Center, Mid-Continent Geographic Science Center, and the Western Geographic Science Center. Other partners include researchers at South Dakota State University, University of Southern Mississippi, and State University of New York College of Environmental Science and Forestry. 


\section{Contents}

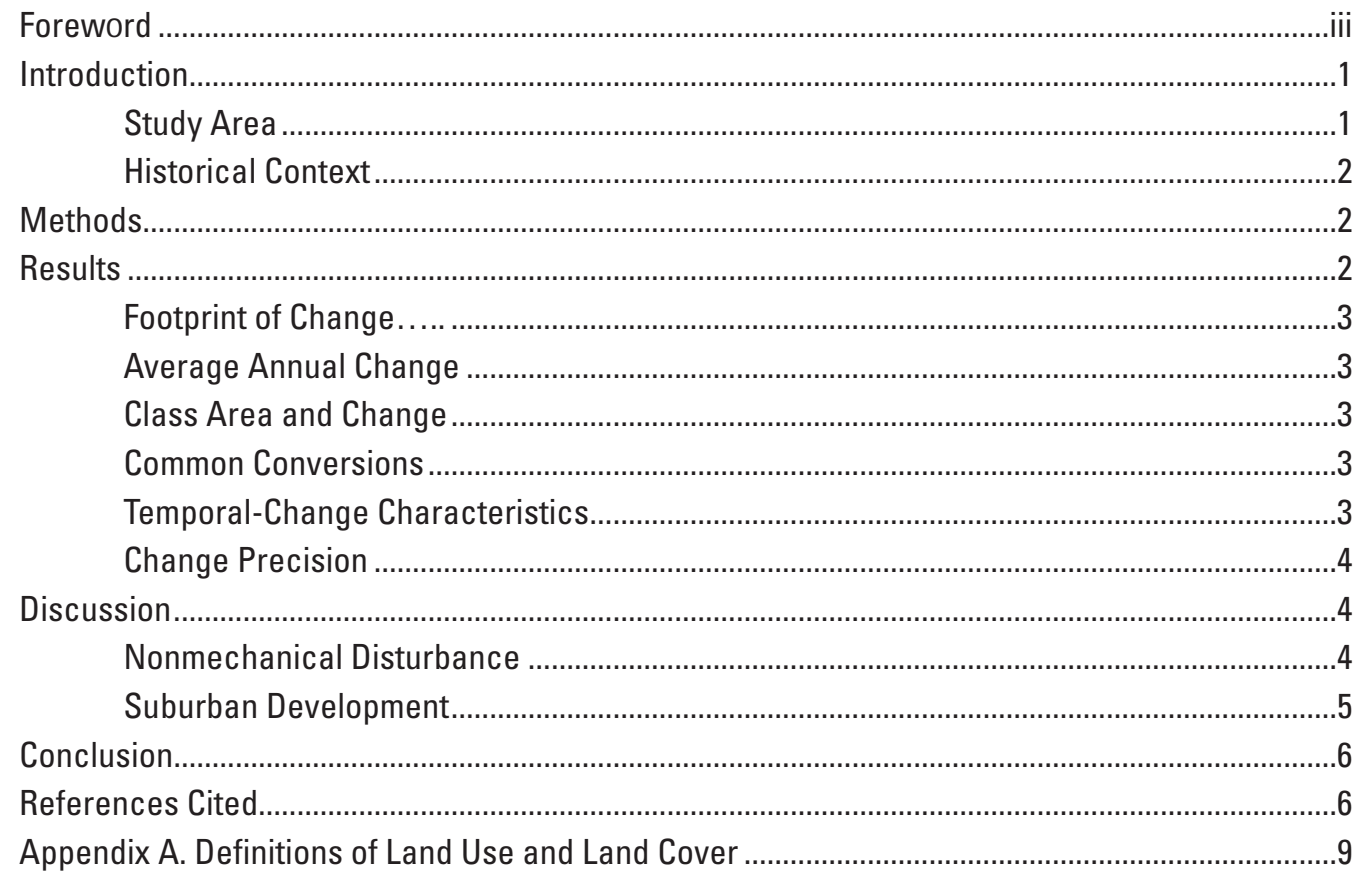

\section{Figures}

1. Location map of the Southern California Mountains Ecoregion...................................................10

2. Map illustrating the major roads of the Southern California Mountains Ecoregion .....................11

3. Land-use/land-cover maps and corresponding Landsat scenes for five dates .........................12

4. Graph illustrating gross change by class over the study period ..................................................13

5. Field photo of area undergoing vegetation reestablishment after a fire.......................................14

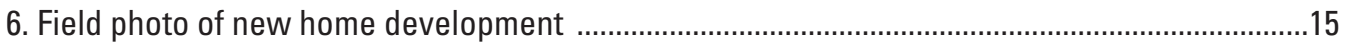

\section{Tables}

1. Percent total land area by class over the study period ............................................................16

2. Most common land-cover conversions over the study period .....................................................16

3. Average annual gains and losses by class ……...............................................................

4. Rates of change related to nonmechanical disturbance .........................................................18

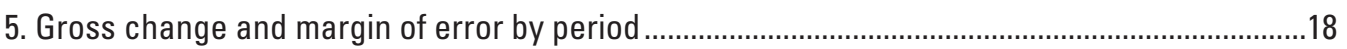




\title{
Land-Cover Trends of the Southern California Mountains Ecoregion
}

\author{
By Christopher E. Soulard, Christian G. Raumann, and Tamara S. Wilson
}

\section{Introduction}

This report presents an assessment of land-use and land-cover (LU/LC) change in the Southern California Mountains ecoregion (fig. 1) for the period 1973-2001. The Southern California Mountains is one of 84 Level-III ecoregions as defined by the U.S. Environmental Protection Agency (EPA) (Environmental Protection Agency, 1999; Omernik, 1987). Ecoregions have served as a spatial framework for environmental resource management, denoting areas that contain a geographically distinct assemblage of biotic and abiotic phenomena including geology, physiography, vegetation, climate, soils, land use, wildlife, and hydrology. The established Land Cover Trends methodology generates estimates of change for ecoregions using a probability sampling approach and changedetection analysis of thematic land-cover images derived from Landsat satellite imagery.

\section{Study Area}

The Southern California Mountains ecoregion (SCME) strata encompasses $17,800 \mathrm{~km}^{2}$ of land bordered to the north by the Central Valley and Sierra Nevada Mountains, to the east by the Mojave Desert, to the southeast by the Sonoran Desert, and to the west by the Los Angeles and San Diego Basins. The SCME is located entirely within the State of California and includes many of the Pacific Coast mountain ranges. From northwest to southeast, these are the Santa Ynez Mountains, the Tehachapi Mountains, the San Gabriel Mountains, the San Bernardino Mountains, the San Jacinto Mountains, and the Santa Rosa Mountains. These ranges are primarily composed of Mesozoic granitic rock, with a few sedimentary and metamorphic exceptions. Additionally, most of the mountains in the SCME are quite fractured and transverse in nature (oriented east to west), due to the San Andreas Fault and associated thrust faults that underlie the region.

The mountains of Southern California act as a barrier between a coastal Mediterranean climate to the west and a dry desert climate to the east. This physiographic barrier effect, along with the topographical gradient of rolling hills to mountains, not only dictates regional land-use patterns, but also influences the patterns of land cover. In terms of land use, the majority of urban lands and agricultural development (for example, irrigated pasture, hay fields, and orchards) occurs at lower elevations in more temperate parts of the SCME. Much of this land use is also connected to the suburban growth occurring in adjacent ecoregions; cities along the periphery of the SCME - specifically, the cities of Pasadena, Santa Clarita, and Palmdale — have caused a spillover in development into the SCME's foothills. At higher elevations, development is primarily associated with recreation activities and their supporting infrastructure (for example, campgrounds, vacation homes, and ski resorts).

Although the SCME is generally sparsely populated, the largest population concentration in the SCME is located in the northwest coastal part of the region in a stretch of lowlands along Highway 101. Populated areas generally reside along the edge of the SCME and along the numerous highways that run through the SCME - namely, Interstates 5 and 10 between larger cities in other ecoregions (for example, Los Angeles, San Diego, Palm Springs, and Bakersfield). In 2000, the largest SCME cities in terms of population were Santa Barbara (pop. 92,325), Goleta (pop. 55,204), Yucaipa (pop. 41.207), Banning (pop. 23,562), and Tehachapi (pop. 10,957) (National Atlas of the United States, 2005a) (fig. 2). Overall, the SCME has a total population around 500,000 (U.S. Census Bureau, 2000).

The wide range of topographic and climatic conditions within the SCME has led to a wide variety of vegetation zonation and, therefore, natural land-cover patterns. Grasses, chaparral shrublands and oak woodlands are found at lower, drier elevations. Vegetation at this elevation grades towards white pine, ponderosa pine, Jeffrey pine, sugar pine, and lodgepole pine at higher, moister elevations. The Mediterranean climate of winter-wet, summer-dry conditions sets the stage for the annual fire season, occurring from late summer to early fall. Dry conditions on the ground coupled with strong, seasonal Santa Ana winds, created from pressure systems that develop between the coast and the desert, have persistently fueled region-wide, large-scale fires for more than 500 years (Mensing and others, 1999). As a result of this long fire history, many plant species here are fire-adapted. Some conebearing species require fire for cones to open and seeds to 
disperse. Oak species have a thick, fire-resistant bark and can sprout new growth from their trunks.

Regional vegetation diversity contributes to the large faunal diversity in the region. In all, 476 vertebrate species reside within the mountains and coastal areas of Southern California (Veirs and others, 1998). Although anthropogenic land use can pose a threat to animal life, many of the species that reside in the SCME are protected to some degree by the presence of Federal land.

Federal lands are 72.5 percent of the SCME, with the majority (65.9 percent) managed by the U.S. Forest Service (USFS). USFS lands include the Angeles National Forest, Cleveland National Forest, Los Padres National Forest, San Bernardino National Forest, and Sequoia National Forest. Other Federal land agencies include the Bureau of Land Management (BLM) (4.4 percent of the SCME), Department of Defense (DOD) (0.3 percent of the SCME) and the Fish and Wildlife Service (FWS) (0.2 percent of the SCME). DOD lands are limited to U.S. Army Corps of Engineer management of Lake Isabella, whereas FWS holdings include a small portion of Bitter Creek National Wildlife Refuge. Native American lands are concentrated in the southern portion of the SCME, with 12 different tribes controlling 0.2 percent of the region (National Atlas of the United States, 2005b).

\section{Historical Context}

Despite limited modern tribal influence, Native Americans were ubiquitous throughout habitable portions of the ecoregion prior to European settlement. Arrival of Spanish missionaries in the late 1700s marked the first instance of European settlement. Cattle and sheep grazing commenced and soon became an economic staple for local tribes, such as the Cahuilla Indians (Leadabrand, 1965). Spanish and American inhabitation of the area not only led to a decline in tribal autonomy, but also contributed to a shift in Native American land use from low intensity farming to more intensive cattle grazing.

Livestock grazing expanded in the SCME following the California Gold Rush of 1848, but the logging industry was responsible for the first road construction in the ecoregion. Paulino Weaver guided the first logging efforts in the San Gorgonio Pass in the 1840s, and Mormon settlers constructed the first sawmill in 1852 (Leadabrand, 1965; Minnich, 1988). The logging industry flourished between 1880 and 1910, primarily because of the railroads' demand for timber for new railroad ties and firewood for fuel. Timber also aided in the construction of larger communities in the Los Angeles Basin and resort communities in the SCME (for example, Strawberry Valley and Idyllwild) (Leadabrand, 1966).

The second half of the $19^{\text {th }}$ century also marked the advent of mining exploration and dam construction within the SCME. Historic gold mining (gold was first discovered in Holcomb Valley in 1860) was extensive throughout the ecoregion, but unsuccessful in most cases. Perhaps the most successful of these endeavors was the gold rush in Julian, which lasted from 1869 to1880 (Leaderbrand, 1965). Despite the lack of success in gold mining, miners found better success mining for gemstones and limestone (for example, in the Lucerne Valley). The limestone was initially used in regional steel mills, but later used to manufacture cement (Leaderbrand, 1966).

The growth in each major sector of the economy ultimately led to a population increase in the SCME, which placed greater demand for water resources. As a result, dam construction began in the late 1800 s to provide irrigation water to regional farmers. Dams at Lake Hemet (constructed 1890-95) and Lake Arrowhead (1893-1908) marked the first such endeavors, although Lake Arrowhead became a recreation-oriented lake soon after its construction (Leadabrand, 1966). Although many reservoirs were constructed throughout the SCME to meet multipurpose resource-use agendas, in current years a greater emphasis has been placed on the recreational needs of the large metropolitan populations in the Los Angeles and San Diego Basins to the west of the SCME.

\section{Methods}

Our interpretation team estimated the amount and rate of LU/LC change in the SCME using a stratified random sampling of $30100-\mathrm{km}^{2}(10 \mathrm{~km}$ by $10 \mathrm{~km})$ blocks from the 178 blocks allocated across the ecoregion (fig. 1). We manually interpreted up to 11 classes of LU/LC (appendix A) from five dates $(1973,1980,1985,1992$, and 2001) of archived Landsat Multispectral Scanner (MSS), Thematic Mapper (TM), and Enhanced Thematic Mapper Plus (ETM+) satellite imagery using a 60-meter minimum mapping unit (Anderson and others, 1976) (fig. 3). In addition to manual interpretation of satellite imagery, we used historical aerial photographs, topographic maps, and other ancillary data sources to aid our interpretation. Our LU/LC mapping effort yielded results for five individual dates and four discrete periods for analysis. We then conducted a post-classification comparison of the five dates of thematic LU/LC data for each sample block to generate estimates of LU/LC change for the entire SCME with corresponding margins of error at an 85-percent confidence level. For a more detailed description of Land Cover Trends project methodology, see Loveland and others (2002).

\section{Results}

The following section describes the results of the post classification comparison applied to the five core dates (1973, 1980, 1985, 1992, and 2001) for the $30100-\mathrm{km}^{2}$ sample blocks within the SCME. We created estimates for the SCME by scaling our sampling results up to the entire ecoregion strata $\left(17,800 \mathrm{~km}^{2}\right)$. 


\section{Footprint of Change}

Between 1973 and 2001, the footprint (overall areal extent) of LU/LC change in the SCME was 5.0 percent, or $885 \mathrm{~km}^{2}$. This change can be interpreted as the amount of the SCME that experienced LU/LC change during at least one of the four multi-year periods that make up the entire 28 -year study period. This footprint of change translates to $498 \mathrm{~km}^{2}$ that changed during one period, $284 \mathrm{~km}^{2}$ that changed during two periods, $103 \mathrm{~km}^{2}$ that changed during three periods, and less than $1 \mathrm{~km}^{2}$ that changed throughout all four periods.

\section{Average Annual Change}

The average annual rate of LU/LC change in the SCME from 1973 to 2001 was 0.3 percent per year. This measurement, which normalizes the results for each period to an annual scale, means that the region averaged 0.3 percent $\left(50 \mathrm{~km}^{2}\right)$ of change each year in the 28 -year study period. However, this annual change varied between each of the four periods. Between 1973 and 1980, the annual rate of change in the SCME was 0.2 percent per year, while the annual rate of change increased to 0.4 percent per year from 1980 to 1985 . The normalized annual rate dropped from 1985 to 1992 to 0.3 percent per year, while the final period spanning from 1992 to 2001 experienced a greater drop, down to 0.2 percent per year.

\section{Class Area and Change}

In 2001, our results illustrate the estimated dominance of four of the eleven LU/LC classes (appendix A) in the SCME: grassland/shrubland (65.9 percent), forest (27.5 percent), developed (2.6 percent), and agriculture (1.5 percent). Although six other LU/LC classes cumulatively made up the remaining 2.5 percent of the SCME landscape in 2001, each of these classes made up less than one percent of the ecoregion (table 1). Between 1973 and 2001, the LU/LC types that experienced a measurable net change in relation to the total SCME area include, in descending order, developed ( 0.8 percent increase), grassland/shrubland ( 0.7 percent decrease), and nonmechanically disturbed ( 0.2 percent decrease).

However, net change may not necessarily be the best indicator of within class variability for those classes experiencing spatio-temporal fluctuations. The net change metric often serves to mask LU/LC dynamics, while analysis of gross change (area gained and lost) by individual LU/LC classes by period shows that classes have fluctuated throughout the 28-year study period to a greater degree than net change values may indicate (Raumann and others, 2007) (fig. 4). For example, the water class may have only experienced a net loss of less than 0.1 percent from 1973 to 2001, but instances of open water experienced 0.4 percent gross change in the SCME over the same 28-year period. Moreover, the same nonmechanically disturbed class that experienced a 0.2 percent net decrease between 1973 and 2001 underwent 3.5 percent gross change during the 28-year study period. Figure 4 illustrates the dynamic nature of LU/LC change in the SCME from 1973 to 2001.

\section{Common Conversions}

The "from-to" information afforded by a post classification comparison allowed us to identify LU/LC class conversions and rank these conversions according to their magnitude:

$\begin{aligned} \text { Ranking value } & =\text { Area } \Delta 1973 \text { to } 1980+\text { Area } \Delta 1980 \text { to } 1985 \\ & + \text { Area } \Delta 1985 \text { to } 1992+\text { Area } \Delta 1992 \text { to } 2001\end{aligned}$

Table 2 illustrates the most frequent conversions from 1973 to 2001 in the SCME. Five of the top ten most prominent conversions are connected to nonmechanical disturbance of land cover by fire. Cumulatively, the effect of nonmechanical disturbance on grassland, shrubland, and forest resulted in an estimated $501 \mathrm{~km}^{2}$ of vegetated land-cover loss. However, much of this land experienced ecological succession, or regrowth, after each disturbance event. This regrowth accounts for $531 \mathrm{~km}^{2}$ of vegetated land-cover gain (areas that were disturbed in consecutive periods account for an additional 21 $\mathrm{km}^{2}$ of change). The transitions to the developed class represent other common conversions in the SCME during the study period $\left(146 \mathrm{~km}^{2}\right)$. Less common conversions consisted of the transitions to and from the water class and shifts in agricultural land use.

\section{Temporal-Change Characteristics}

We measured significant temporal variability in certain LU/LC classes in the SCME throughout the 28-year study period. In certain instances, LU/LC changes tended to be unidirectional in nature, changing rather consistently in each of the four periods. Developed land not only represents the only land use that had a significant increase between 1973 and 2001, but also stands alone as the only land-use class that did not experience any decline in each of the four periods. Between 1973 and 1980, the developed class averaged a net annual increase of $5.9 \mathrm{~km}^{2}$ per year. During the next two periods, development in the SCME averaged an annual increase of $7.2 \mathrm{~km}^{2}$ per year (1980-1985) and $6.2 \mathrm{~km}^{2}$ per year (19851992). During the final period from 1992 to 2001, developed land continued to increase, but at a lower rate of $2.9 \mathrm{~km}^{2}$ per year (table 3).

Although expansion of anthropogenic land uses such as development had an inverse and a measurable influence on background land-cover types, nonmechanical disturbance events (exclusively in the form of fire) had the most significant impact on the temporal variability of grass/shrubland and forest changes in the SCME throughout the study period. The average areal extent of fire disturbance, as represented by the conversion of vegetated lands to the nonmechanically disturbed class, was $7.0 \mathrm{~km}^{2}$ per year averaged from 1973- 
1980, with an increase to $53.9 \mathrm{~km}^{2}$ per year from 1980-1985. During the 1985-1992 and 1992-2001 periods, the conversion to nonmechanically disturbed lands decreased to $9.5 \mathrm{~km}^{2}$ per year and $15.4 \mathrm{~km}^{2}$ per year, respectively. The rate of vegetation regeneration after fire, represented by the conversion of land from nonmechanical disturbance to vegetation classes, mirrors the rate of fire disturbance. Regeneration increased during the period following a period of higher rates of fire disturbance and decreased after a period of lower rates of fire disturbance (Raumann and others, 2007) (table 4). In the SCME, 89 percent of this regeneration occurred as conversion to grass/ shrubland, whereas the remaining 11 percent occurred as a conversion to forest.

\section{Change Precision}

LU/LC change estimates for each of the four time periods (1973-1980, 1980-1985, 1985-1992, and 1992-2001) are stated by a margin of error at an 85 -percent confidence interval (table 5). Only one of the four periods had a margin of error within $+/$ - one percent at an 85 percent confidence. These larger errors are directly related to the high amount and uneven distribution of gross change across the SCME $(1,410$ $\mathrm{km}^{2}$ ). In terms of change distribution, ecoregions with uneven pockets of change require a greater sampling density to reduce uncertainty in change estimates. Therefore, increasing the number of sample blocks in the SCME would likely reduce the region's margin of error. A more complete explanation of Land Cover Trends sampling design and sampling uncertainty is provided by Stehman and others (2003) and Loveland and others (2002).

\section{Discussion}

Changes and overall LU/LC trends in the SCME can be attributed to various driving forces. Here, we explain these possible drivers based on both existing literature and direct field observation. In some cases, drivers of change are unique to a given landscape. However, we will also explore how certain drivers may influence change in multiple LU/LC types. In addition, we will examine how changes in one LU/LC class may influence change in another. Understanding both the positive and negative feedback mechanisms driving change within and among LU/LC classes will illustrate the overall interdependence of land dynamics within the ecoregion. On the basis of our change estimates, we can make some generalizations about the possible drivers of change and the potential implications of these changes in the future.

\section{Nonmechanical Disturbance}

The most dynamic LU/LC conversions in terms of area changed throughout the 28-year study period were conversions pertaining to the nonmechanical disturbance class. Nonmechanical landscape disturbance, which was entirely attributed to fire, typically involved changes from grassland/ shrubland, forest, and previously disturbed lands to the nonmechanically disturbed class. The majority of this change occurred in grassland and chaparral sites at lower elevations, with less change occurring in higher elevation forests of the SCME. In terms of vegetation recovery after a nonmechanical disturbance event, the burnt area either transitioned back to its original land-cover class in the following time period or to an intermediate successional state. Although the latter was masked in shrubland environments due to the generalization of the grassland/shrubland class, the establishment of grasses in some forested areas following a fire illustrated these early stages of secondary succession (table 4).

Fires in grassland, shrubland, and forest landscapes presented a unique suite of problems in terms of manually mapping fire. We integrated a historical fire-perimeters dataset from California Department of Forestry/Fire and Resource Assessment Program (CDF/FRAP) into our manual interpretation to help interpret the Landsat imagery. The CDF/ FRAP database not only contains fire location information from 1910-2001, but also provides ancillary attributes such as ignition date, tracking agency, and cause (California Department of Forestry, 2006). Our detection of fires was consistent with the CDF/FRAP fires database in that each of our mapped fires were included in the database. However, the CDF/FRAP database had many fires mapped within the 28-year study period that we did not map in our study. Factors such as fire intensity/severity, ignition date, and burn area may explain this discrepancy. For example, a grassland/shrubland area many have burned immediately following one of our imagery dates and fully recovered to pre-burn conditions by our next Landsat imagery date (or burned multiple times). As for forested areas, many of the prescribed burns used to thin forested lands may not have been large enough or severe enough to map with our 60-meter mapping unit.

The former fire cycle under which plant and animal species evolved has changed with increasing human populations and implementation of fire suppression efforts in the $20^{\text {th }}$ century. In the past, natural ignition sources such as lightning and wind dictated fire behavior in the SCME, but today most of the fires are human-caused and are located at or near the interface between human development and wild lands (U.S. Department of Agriculture, 2005) (fig. 3). Although debate still exists regarding whether or not fire suppression efforts have offset the effects of human caused fires on a whole within the SCME, existing research clearly indicates that humans have changed the nature of these fires in terms of frequency, size, and location (Minnich and others, 1995; Keeley and others, 1999; Stephenson and others, 1999; California Department of Fish and Game, 2006). According to Keeley and others (1999), increasing encroachment of human populations into wildlands is highly correlated with increased fire frequency and decreased fire return intervals. For example, the addition of the human element has increased the frequency of fires by 
increasing artificial ignitions, while suppression efforts have kept many of these fires small in size. As a result, the SCME's landscape appears to have more of a patchwork appearance compared to areas with limited human presence or without suppression programs (for example, Baja California, Mexico; see Minnich, 1983). Suppression efforts have led to the reduction of fires in montane woodlands, while the presence of the urban interface has increased the frequency of fires in the grassland/shrubland land cover at lower elevations, shifting the actual location of where fires occur (fig. 5).

Although the human element plays a pivotal role in the occurrence of fire in the SCME, the cyclic ecoregion-wide signal of fire occurrence followed by grassland regeneration also follows the well documented cyclic process of interannual climate variability associated with El Niño. The influence of El Niño is well established for Southern California. In general, El Niño events bring higher than normal winter rainfall with the southern displacement of the jet stream, whereas La Niña events are associated with anomalously dry winters. Higher than normal rainfall during an El Niño winter increases available fuel load, whereas the subsequent dry years deplete vegetation fuel moisture, creating optimal fire conditions. Antecedent wet years followed by subsequent dry years have already been shown to increase fire occurrence in southwestern forests (Swetnam and others, 1990; Swetnam and others, 1999). Historic dendrochronological records from Northern Baja California also indicate large fires occurring in anomalously dry years (Stephens and others, 2003). Occurring the year after our core date of 1992 and 1 year after a significant El Nino winter, the 1993 fire season greatly impacted the region at an estimated cost of 1.3 billion dollars (Lott and others, 2006). The most recent occurrence of this sort occurred in late 2003, when more than 700,000 acres burned in the SCME following 5 years of drier than normal conditions. Estimated costs of this latest disaster alone were 2.5 billion dollars (Lott and others, 2006).

Economic losses are not the only consequence of fire in SCME. Changes in the historical fire regime can also threaten ecological diversity in the area by creating a more fragmented landscape that may effectively inhibit the dispersal mechanisms of some species, while enabling the rapid encroachment of others. For example, the closed-coned Tecate cypress (Cupressus forbesii) requires fire to release seeds from the cone, but increased fire frequency can wipe out local sapling populations before they are mature enough to produce seed (White and others, 1995). Conversely, seedling establishment in Coulter pines (Pinus coulteri) is prolific following a fire, as seedlings flourish in full sun (U.S. Department of Agriculture, 2005). At lower elevations, a different story emerges. The most dramatic fire-induced changes here occur in coastal sage and buckwheat scrub communities where frequent fires have been shown to significantly degrade habitat quality (Stephenson and others, 1999). Loss of shrub cover creates opportunities for the invasion of nonnative annual grasses, such as cheatgrass, which inhibit future reestablishment of scrubland vegetation.
Changes in plant cover and abundance will invariably lead to changes in faunal distribution. Recent declines in California spotted owl populations have been attributed to fires that eliminate tree stands as well as the lack of riparian corridors linking SCME's discontinuous mountain ranges (White and others, 1995). Other endangered species whose habitats have recently suffered fire-associated habitat decline include the Quino checkerspot butterfly (Euphydryas editha quino), coastal California gnatcatcher (Polioptila californica californica), Least Bell's vireo (Vireo bellii pusillus), and mountain yellow-legged frog (Rana muscosa) (Center for Biological Diversity, 2007).

\section{Suburban Development}

Mid $20^{\text {th }}$ century development in the SCME primarily consisted of recreational development - campgrounds, resort communities (for example, Lake Arrowhead), and vacation homes. This type of development provided a temporary getaway for tourists from adjacent areas. However, the SCME's rugged terrain deterred most people from taking up permanent residence. Recreational development continues to thrive throughout the SCME (for example, Mountain High Ski Resort and Pine Mountain Club), but a suite of driving forces has contributed to new development in the region.

Development in the basin just west of the SCME consists of Los Angeles and San Diego, two of the most populated metropolitan areas in the Untied States. Additionally, Bakersfield borders the SCME to the north and Palm Springs flanks the SCME to the east. The SCME not only acts as a thoroughfare between these cities (with an extensive and ever-changing road network) but also represents a location for suburban expansion to accommodate a nearly fivefold increase in population in surrounding areas since 1940 (California Department of Finance, 2004; Southern California Association of Governments, 2006) (fig. 6). In recent decades, suburban development along the ecoregion - specifically, the cities of Pasadena, Santa Clarita, and Palmdale - has caused a spillover in development into the SCME's foothills (fig. 3). This spillover accounts for a large part of the urban change that we detected between 1973 and 2001.

Although this increase in population may contribute to economic benefits such as increased tourism and commerce, these changes do not come without an environmental cost. The consequences of development are often the same as fire in the SCME, such as the eradication of floral and faunal habitat. For instance, both development and fire tend to occur in the lower elevations of the SCME, a landscape where grass/shrubland is the primary land cover. The loss of approximately 80 percent of coastal sage scrub has been attributed to development in the coastal basins. This land cover is also the primary habitat of the California gnatcatcher and other endangered species (Stephenson and others, 1999). Loss of grass/shrubland pushes some species to marginal habitat and may contribute to the creation of disjunct populations and habitat fragmentation. 
Continued development will place additional limits on range size, continuity, and connectivity (Kattan and others, 1994; Knick and others, 1995).

LU/LC conversions may also indirectly affect quality of animal life by increasing water and air pollution. For example, development adds to the impervious surface area of the landscape through roads, structures, dams, and other manmade features. This, in turn, changes surface and ground-water hydrology, including increased surface water temperatures, higher flood frequency, increased erosion potential, and water pollution concentrations (for example, sediments, metals, fertilizers, and pesticides) (Raumann and others, 2007; Jones and others, 2001; Barnes and others, 2000). These changes not only impact wildlife, but also pose a threat to humans by increasing the toxicity of drinking water and the potential of hazardous events. Regional development also facilitates heavy vehicle use within and around the SCME, producing high concentrations of ozone and nitrogen in the region's atmosphere (Lee and others, 2003). These pollutants cause increased tree mortality, alter species dynamics, and eventually runoff into streams (causing increased water nitrate concentrations) (Takemoto and others, 2001; Stephenson and others, 1999).

\section{Conclusion}

The SCME is a geographically unique place, nearly surrounded at lower elevations by human development with few natural corridors linking its composite mountain ranges. Population expansion and contact with wildland areas are changing the historical fire regime. These anthropogenic changes make predictions of future ecosystem health difficult as threats and outcomes cannot be measured against historical conditions. Topographic isolation coupled with increased fragmentation of habitat by fire pose significant threats to existing diversity and may ultimately drive species turnover in SCME. Protection of this designated biodiversity hotspot will become increasingly difficult given current LU/LC trends (Myers and others, 2000). On Federal lands, many agencies have had to adopt multiscale integrated planning and management activities in an attempt to deal with these ecological processes within their given management unit (Hann and others, 2001). However, the consequences of LU/LC trends for nonmechanical disturbance, loss of grass/shrubland, and development do not necessarily follow managerial boundaries.

Our description of contemporary LU/LC change trends in the SCME illustrates the benefit of multi-temporal analysis and reinforces the interconnection between regional land use and land cover. As the Land Cover Trends team continues to interpret change for other ecoregions within the United States, we are exploring methods to refine our change estimates and the corresponding margin of error with tools such as regression estimators and post-stratification techniques (Stehman and others, 2003). Additionally, completing additional ecoregions will provide the opportunity to compare change estimates between ecoregions in an attempt to learn about the variability of change between different landscapes and will allow results to be merged to create estimates for larger geographic assemblages, such as California, or the Western United States.

\section{References Cited}

Anderson, J.P., Hardy, E.E., Roach, J.T., and Witmer, R.E., 1976, A land use and land cover classification system for use with remote sensor data: U.S. Geological Survey Professional Paper 964.

Barnes, K.B., Morgan, J.M., III, and Roberge, M.C., 2000, Impervious surfaces and the quality of natural and built environments - A white paper prepared for the project, Chesapeake Bay from Space: [http://chesapeake.towson. edu/ (last accessed June 13, 2007)].

California Department of Fish and Game, 2006, Chapter 9, South Coast Region, in California's Wildlife Action Plan: California Department of Fish and Game, p. 163-193.

California Department of Finance, 2004. P3 population projections by race/ethnicity, gender and age for California and its counties 2000-2050: Sacramento, California: [http://www. oshpd.ca.gov/charts/popu/ (last accessed June 13, 2007)].

California Department of Forestry, 2006, Fire Perimeters: California Department of Forestry Fire and Resource Assessment Program.

Center for Biological Diversity, 2007, Impacts of the 2003 Southern California wildfires on four species listed as threatened or endangered under the Federal Endangered Species Act - Quino checkerspot butterfly, Mountain yellow-legged frog, Coastal California gnatcatcher, Least Bell's vireo: [http://www.biologicaldiversity.org/swcbd/Programs/fire/report-2003.pdf (last accessed June 18, 2007)].

Environmental Protection Agency, 1999, Level III Ecoregions of the Continental United States: U.S. Environmental Protection Agency, National Health and Environmental Effects Research Laboratory, Corvallis, Oregon, 1:7,500,000-scale map.

Hann, W.J., and D.L., B., 2001, Fire and land management planning and implementation across multiple scales: International Journal of Wildland Fire, v. 10, p. 389-403.

Jones, K.B., Neale, A.C., Nash, M.S., Van Remortel, R.D., Wickham, J.D., Riitters, K.H., O’Neill, R.V., 2001, Predicting nutrient and sediment loadings to streams from landscape metrics - A multiple watershed study from the United States Mid-Atlantic Region: Landscape Ecology, v. 16, n. 4, p.301-312. 
Kattan, G.H., Alvarez-Lopez, H., and Gerald, M., 1994, Forest fragmentation and bird extinctions - San Antonio eighty years later: Conservation Biology, v. 8, n. 1, p. 138-146.

Keeley, J.E., Fotheringham, C.J., and Morais, M., 1999, Reexamining Fire Suppression Impacts on Brushland Fire Regimes: Science, v. 284, p. 1829-1832.

Knick, S.T., and Rotenberry, J.T., 1995, Landscape characteristics of fragmented shrub steppe habitats and breeding passerine birds: Conservation Biology, v. 9, n. 5, p. 1059-1071.

Leadabrand, R., 1965, A guidebook to the Sunset Ranges of Southern California: Los Angeles, Calif., The Ward Ritchie Press.

Leadabrand, R., 1966, A guidebook to the San Bernardino Mountains of California: Los Angeles, Calif., The Ward Ritchie Press.

Lee, E.H., Tingey, D.T., Hogsett, W.E., and Laurence, J.A., 2003, History of tropospheric ozone for the San Bernardino Mountains of Southern California, 1963-1999: Atmospheric Environment, v. 37, p. 2705-2717.

Lott, N., and Ross, T., 2006, Tracking and evaluating U.S. billion dollar weather disasters, 1980-2005: National Oceanic and Atmospheric Administration National Climatic Data Center: [http://wwwl.ncdc.noaa.gov/pub/data/ papers/200686ams1.2nlfree.pdf (last accessed August 30, 2007)].

Loveland, T.R., Sohl, T.L., Stehman, S.V., Gallant, A.L., Sayler, K.L., and Napton, D.E., 2002, A strategy for estimating the rates of recent United States land-cover changes: Photogrammetric Engineering and Remote Sensing, v. 68, no. 10, p. 1091-99.

Mensing, S.A., Michaelson, J., and Byrne, R., 1999, A 560year record of Santa Ana fires reconstructed from charcoal deposited in the Santa Barbara Basin, California: Quaternary Research, v. 51, p. 295-305.

Minnich, R.A., 1983, Fire mosaics in Southern California and Northern Baja California: Science, v. 219, p. 1287-1294.

Minnich, R.A., 1988, The biogeography of fire in the San Bernardino Mountains, California - A historical study: Berkeley, Calif., University of California Press.

Minnich, R.A., Barbour, M.G., Burk, J.H., and Fernau, R.F., 1965, Sixty years of change in Californian conifer forests of the San Bernardino Mountains: Conservation Biology, v. 9, no. 4, p. 902-914.

Myers, N., Mittermeier, R.A., Mittermeier, C.G., da Fonseca, G.A.B., and Kent, J., 2000, Biodiversity hotspots for conservation priorities: Nature, v. 403, p. 853-858.
National Atlas of the United States, 2005a, Cities and towns of the United States: [http://www.nationalatlas.gov/atlasftp. html\#fedlanp (last accessed October 15, 2006)].

National Atlas of the United States, 2005b, Federal lands of the United States: [http://www.nationalatlas.gov/atlasftp. html\#fedlanp (last accessed October 15, 2006)].

National Atlas of the United States, 2005c, Major roads of the United States: [http://www.nationalatlas.gov/atlasftp. html\#fedlanp (last accessed June 20, 2007)].

Omernik, J.M., 1987, Ecoregions of the conterminous United States: Annals of the Association of American Geographers, v. 77 , p. 118-125.

Raumann, C.G., and Soulard, C.E., 2007, Land-cover trends in the Sierra Nevada ecoregion, 1973-2000: U.S. Geological Survey Scientific Investigation Report 2007-5011.

Southern California Association of Governments, 2006, Census data: [http://www.scag.ca.gov/census (last accessed June 13, 2007)].

Stehman, S.V., Sohl, T.L., and Loveland, T.R., 2003, Statistical sampling to characterize recent United States land-cover change: Remote Sensing of Environment, v. 86, p. 517-529.

Stephens, S.L., Skinner, C.N., and Gill, S.J., 2003, Dendrochronology-based fire history of Jeffrey pine — Mixed conifer forests in the Sierra San Pedro Martir, Mexico: Canada Journal of Forest Research, v. 33, p. 1090-1101.

Stephenson, J.R., and Calcarone, G.M., 1999, Southern California mountains and foothills assessment - Habitat and species conservation Issues: United States Department of Agriculture, Forest Service, Pacific Southwest Research Station General Technical Report PSW-GTR-172.

Swetnam, T.W., and Betancourt, J.L., 1990, Fire-southern oscillation relations in the southwestern United States: Science, v. 249, p, 1017-1020.

Swetnam, T.W., Allen, C.D., and Betancourt, J.L., 1999, Applied historical ecology - Using the past to manage the future: Ecological Applications, v. 9, no. 4, p. 1189-1206.

Takemoto, B.K., Bytnerowicz, A., and Fenn, M.E., 2001, Current and future effects of ozone and atmospheric nitrogen deposition on California's mixed conifer forests: Forest Ecology and Management, v. 144, p. 159-173.

U.S. Census Bureau, 2000, U.S. Census Database - Population: U.S. Census Bureau: [http://factfinder.census.gov/ home/saff/main.html?_lang=en (last accessed August 30, 2007)]. 
U.S. Department of Agriculture, 2005, Final environmental impact statement, volume 1, Land management plans: United States Department of Agriculture, Forest Service, Pacific Southwest Region R5-MB-074-A.

Veirs, S.D., Jr., Opler, P.A., Gilmer, D.S., Graber, D.M., Graham, T., Huckaby, L.S., Jennings, M.R., McEachern, K., Moyle, P.B., and Stefani, R.A., 1998, California, in Mac, M.J., Opler, P.A., Puckett Haeker, C.E., and Doran, P.D., eds., Status and trends of the nation's biological resources: Reno, Nevada, U.S. Geological Survey, v. 2: [http://biology. usgs.gov/s+t/SNT/noframe/cal62.htm (last accessed June 13, 2007)].
Vogelmann, J.E., Howard, S.M., Yang, L., Larson, C.R., Wylie, B.K., and van Driel, N., 2001, Completion of the 1990s National Land Cover Data Set for the conterminous United States from Landsat Thematic Mapper data and ancillary data sources: Photogrammetic Engineering and Remote Sensing, v. 67, p. 650-662.

White, S.D., and Pantoja, M., 1995, Fire Management for Rare Plants and Animals, in Keeley, J.E., and Scott, T., eds., Brushfires in California woodlands: Fairfield, Wash., Ecology and Resource Management, p. 41-44. 


\section{Appendix A. Definitions of Land Use and Land Cover}

The following are the general land-cover definitions that will be used in the project. To the extent possible, the definitions reflect the original Anderson and others (1976) level-I definitions so that land-cover data developed through the Land Cover Trends project are consistent with those produced through other programs and projects. A minimum mapping unit of 60 meters will used to determine land-cover.

Developed - Areas of intensive use with much of the land covered with structures (for example, high density residential, commercial, industrial, or transportation) or less intensive uses where the land-cover matrix includes both vegetation and structures (for example, low density residential, recreational facilities, cemeteries, or transportation and utility corridors), including any land functionally related to the developed or built-up activity.

Cropland and Pasture - Land in either a vegetated or unvegetated state used for the production of food and fiber. This includes cultivated and uncultivated croplands, hay lands, pasture, orchards, vineyards, and confined livestock operations. Note that forest plantations are considered as forests or woodlands regardless of the use of the wood products.

Forests and Woodland - Tree-covered land where the tree-cover density is greater than 10 percent. Note that cleared forest land (for example, clearcuts) will be mapped according to current cover (for example, disturbed or transitional, shrubland/grassland).

Shrubland/Grassland - Land predominately covered with grasses or shrubs. The vegetated cover must be at least 10 percent of the area.
Wetland - Lands where water saturation is the determining factor in soil characteristics, vegetation types, and animal communities. Wetlands are comprised of water and vegetated cover.

Water Bodies - Areas persistently covered with water, such as streams, canals, lakes, reservoirs, bays, or oceans.

Snow and Ice - Land where the accumulation of snow and ice does not completely melt during the summer period.

Barren - Land comprised of natural occurrences of soils, sand, or rocks where less than 10 percent of the area is vegetated.

Mining - Areas with extractive mining activities that have a significant surface expression. This includes (to the extent that these features can be detected) mine buildings, quarry pits, overburden, leach, evaporative, tailing, or other related components.

Mechanical Disturbed or Transitional - Land in an altered unvegetated state that, due to disturbances by mechanical means, is in transition from one cover type to another. Mechanical disturbances including forest clear cutting, earthmoving, scraping, chaining, reservoir draw down, or other related human-induced changes.

Nonmechanical Disturbed or Transitional - Land in an altered unvegetated state that, due to disturbances by nonmechanical means, is in transition from cover type to another. Nonmechanical disturbances include wind, floods, fire, animals, and other related sources. 


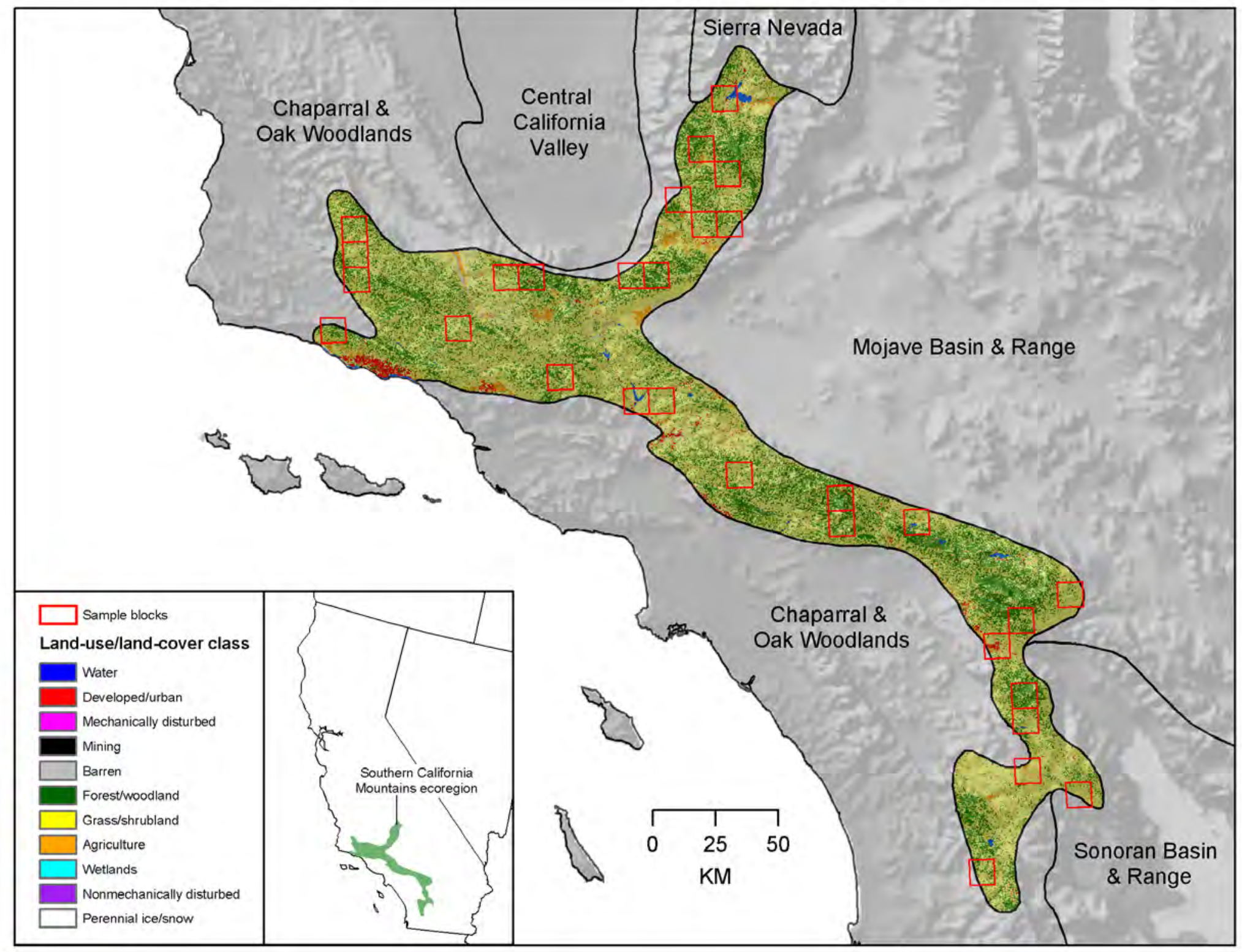

Figure 1. Southern California Mountains ecoregion and surrounding ecoregions. Information shown includes land-use/land-cover data from the 1992 National Land Cover Dataset (Vogelmann and others, 2001) and the 30 randomly selected $100 \mathrm{~km}^{2}$ blocks discussed in text. 


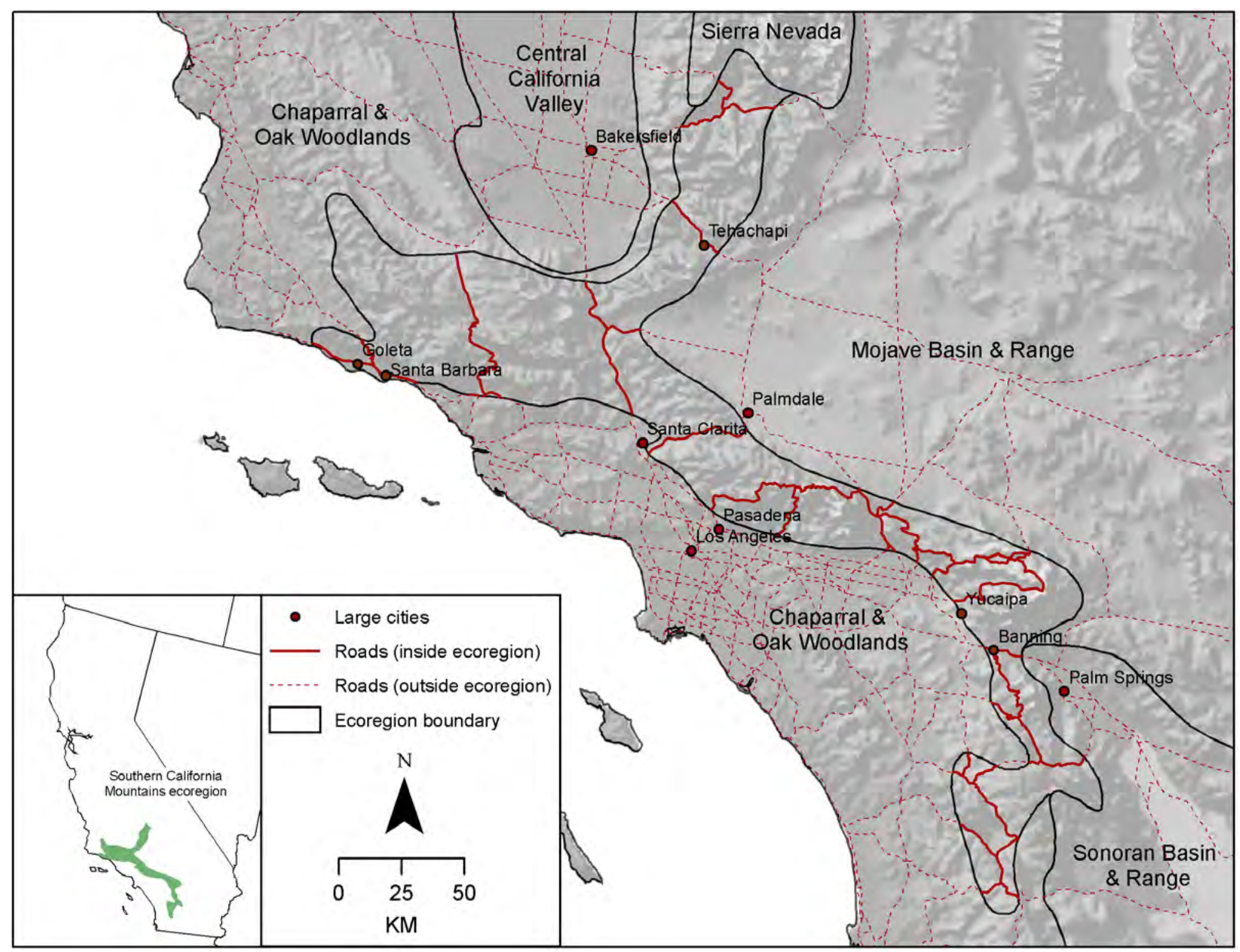

Figure 2. Southern California Mountains ecoregion and surrounding ecoregions. Information shown includes partial road and city data from the National Atlas (National Atlas, 2005c). 


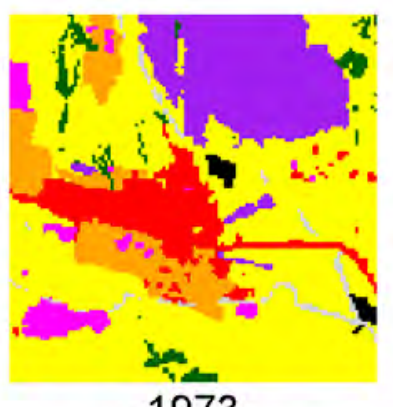

1973
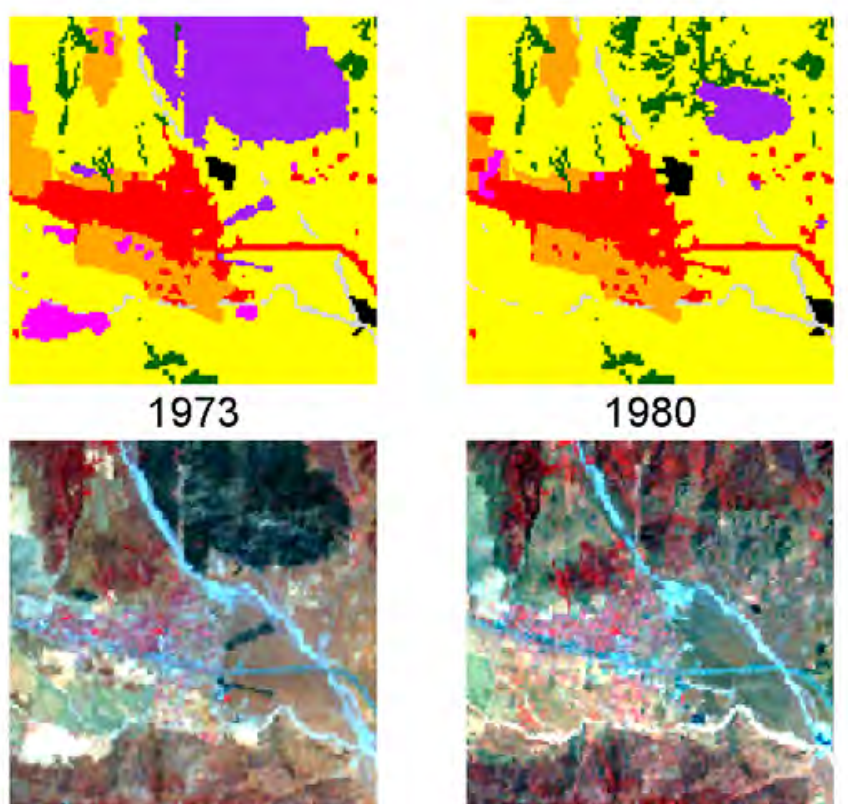

st.

1980
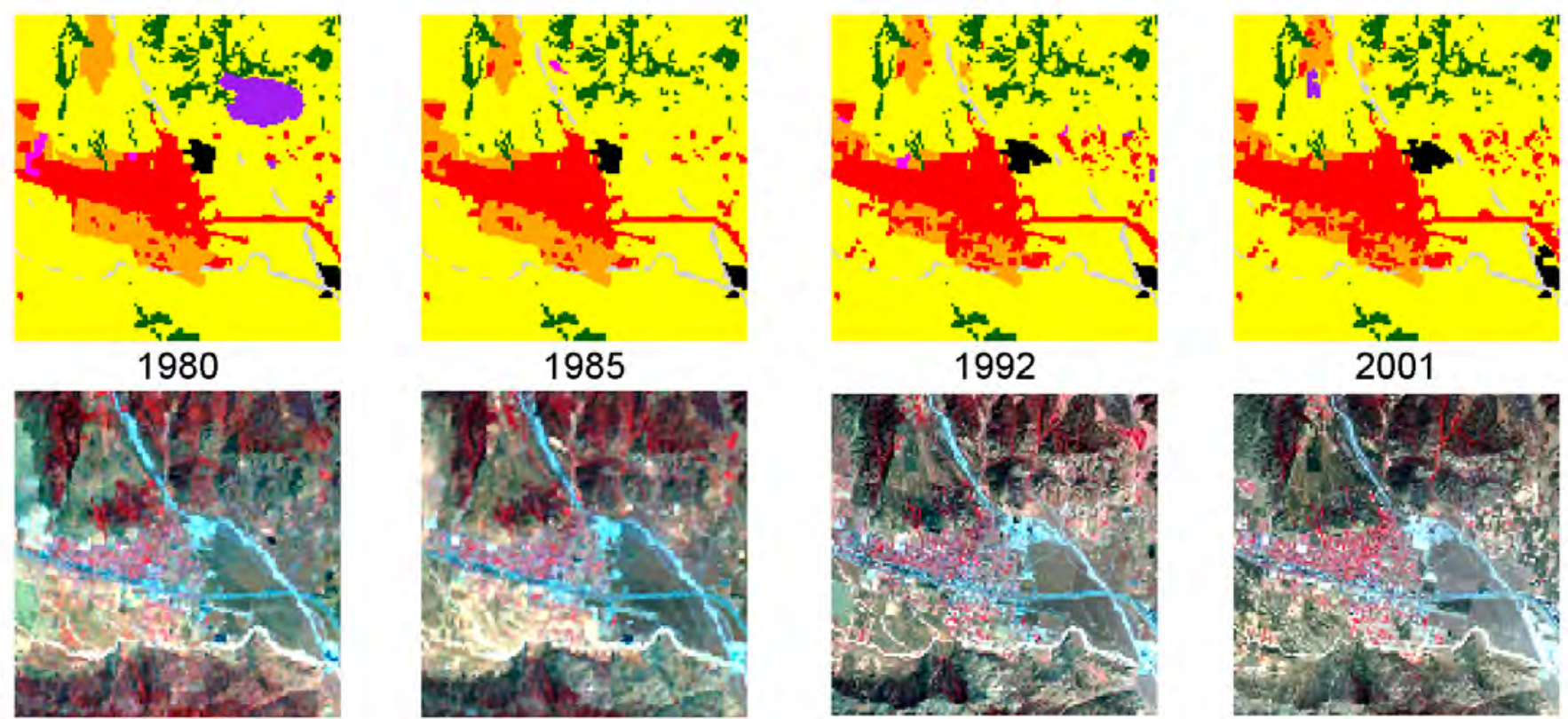

Land-use/land-cover maps (above) interpreted from Landsat imagery (below). Land-use/land-cover classes as follows:

water

Developed/urban

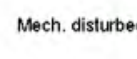

Mining
Barren

Forest/woodland

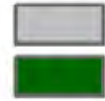

Grass/shrubland

Agricuture

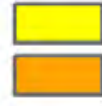

Wetlands

Nonmech. disturbed

Figure 3. A single 100-km² sample block located in the foothills of the Southern California Mountains ecoregion. Dominant land-use/land-cover conversions include expansion of development into agriculture and grass/shrubland and conversions to/from nonmechanically disturbed land, which illustrates the fire/vegetation regeneration process. [Mech., mechanically; Nonmech., nonmechanically] 
Gains and Losses by Land-Use/Land-Cover Class

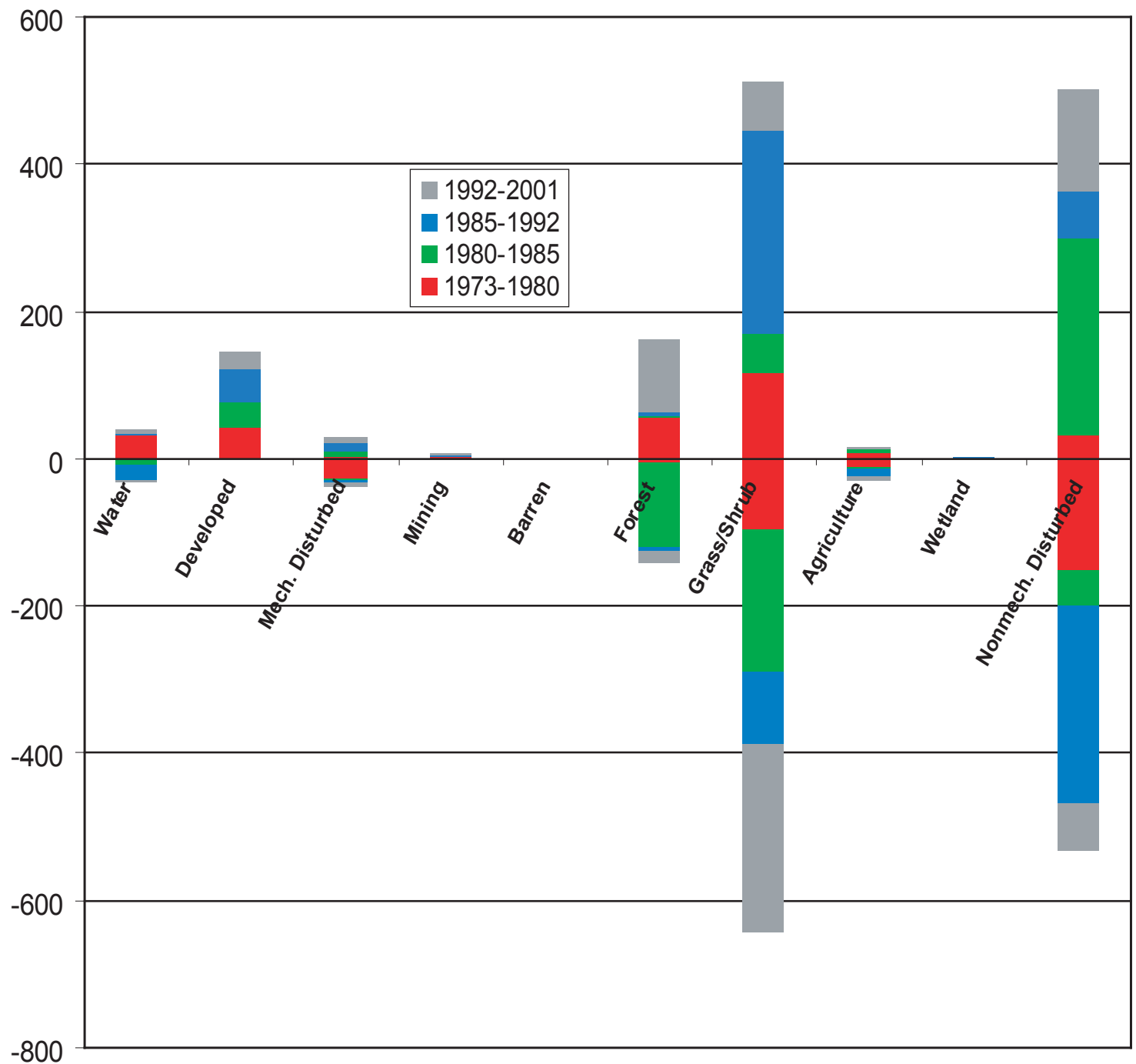

Figure 4. Gross change in land use/land cover for each of the four periods studied. This diagram illustrates how net change can mask within class fluctuations within each period and for the entire 28-year study period. [Mech., mechanically; Nonmech., nonmechanically] 


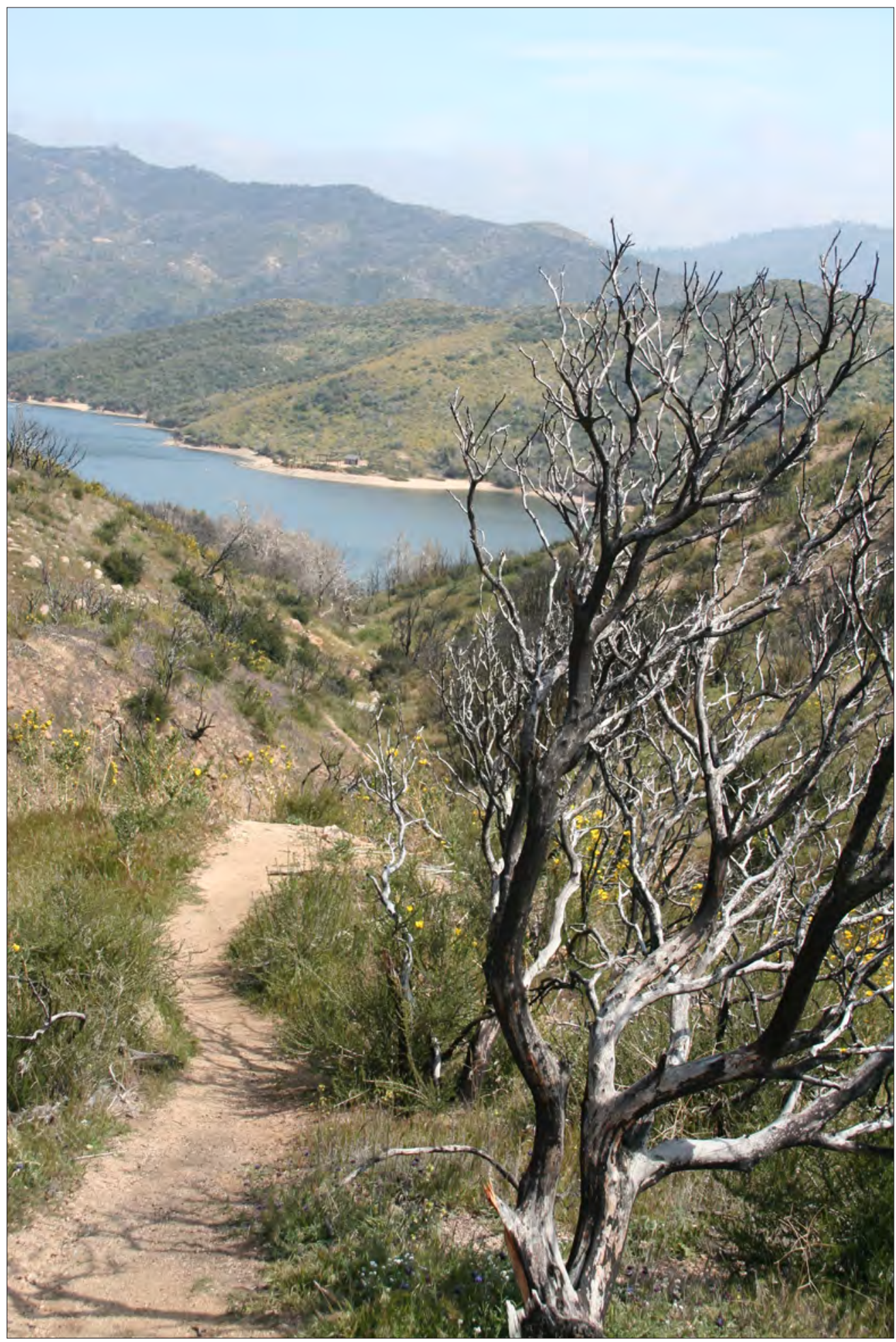

Figure 5. Field photo taken April 2005 of an area by Silverwood Lake, Calif., undergoing regeneration following a fire. Although grasses and shrubland tend to reestablish quite soon after a fire, trees take much longer to recover. Land-cover types shown are grass/shrubland and water. 


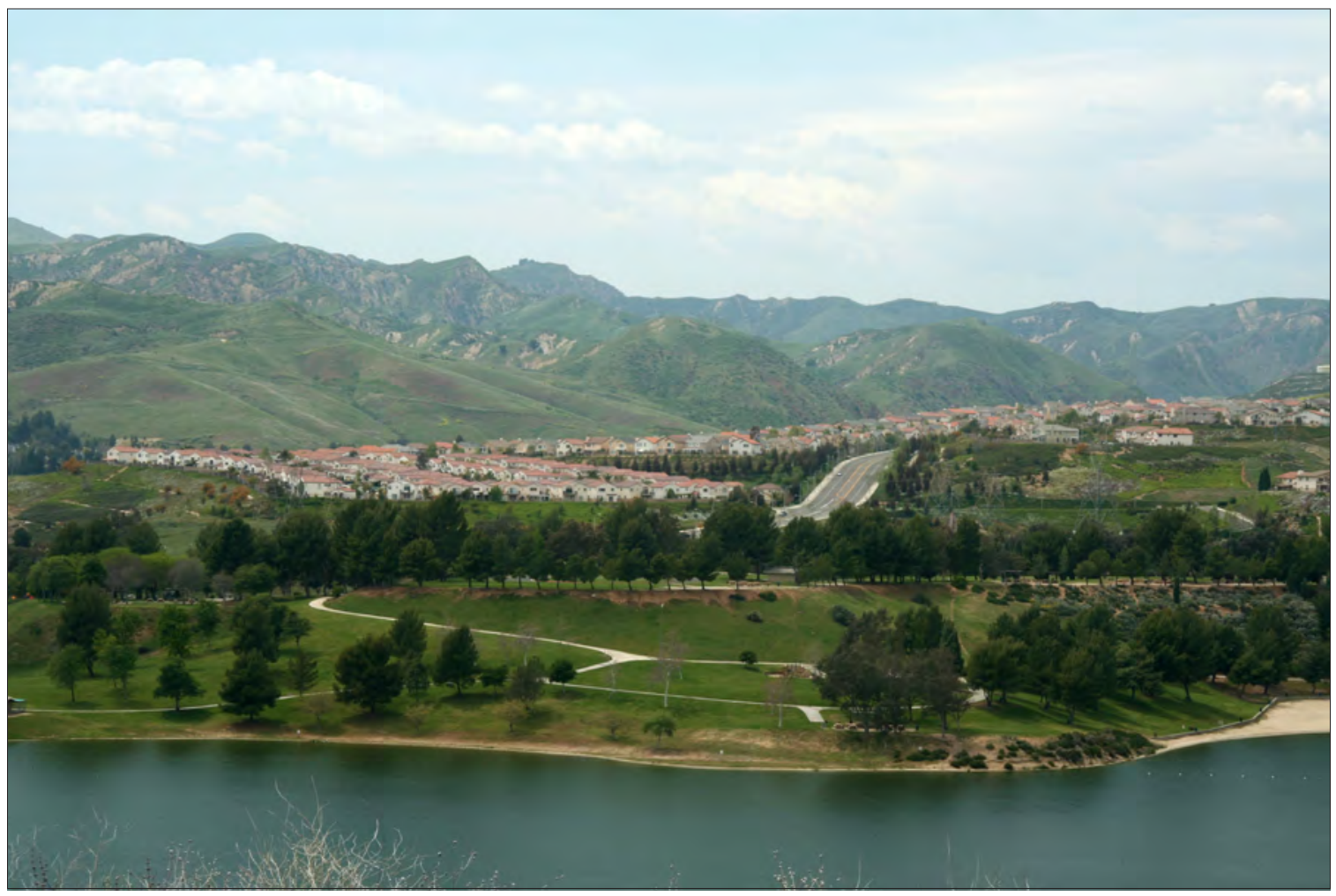

Figure 6. Field photo taken April 2005 of new homes in Castaic, Calif. Castaic is an unincorporated community in Los Angeles County that is located along Interstate 5. Land-use/land-cover types shown are grass/shrubland, forest, developed, and water. 
Table 1. Land-use/land-cover class area as a percentage of the Southern California Mountains ecoregion strata area (17,800 km²).

\begin{tabular}{|c|c|c|c|c|c|c|c|c|}
\hline Land-use/cover class & 1973 & 1980 & 1985 & 1992 & 2001 & \multicolumn{3}{|c|}{ Net change, 1973-2001 } \\
\hline Water & $0.8 \%$ & $1.0 \%$ & $0.9 \%$ & $0.8 \%$ & $0.8 \%$ & 7.8 & $0.0 \%$ & $5.5 \%$ \\
\hline Developed & $1.8 \%$ & $2.1 \%$ & $2.3 \%$ & $2.5 \%$ & $2.6 \%$ & 145.8 & $0.8 \%$ & $44.8 \%$ \\
\hline Barren & $0.5 \%$ & $0.5 \%$ & $0.5 \%$ & $0.5 \%$ & $0.5 \%$ & 0.2 & $0.0 \%$ & $0.3 \%$ \\
\hline Forest & $27.4 \%$ & $27.7 \%$ & $27.0 \%$ & $27.0 \%$ & $27.5 \%$ & 21.4 & $0.1 \%$ & $0.4 \%$ \\
\hline Grass/Shrubland & $66.6 \%$ & $66.7 \%$ & $65.9 \%$ & $66.9 \%$ & $65.9 \%$ & -130.1 & $-0.7 \%$ & $-1.1 \%$ \\
\hline Agriculture & $1.6 \%$ & $1.5 \%$ & $1.5 \%$ & $1.5 \%$ & $1.5 \%$ & -13.4 & $-0.1 \%$ & $-4.8 \%$ \\
\hline
\end{tabular}

Table 2. Most common land-use/land-cover conversions in the Southern California Mountains ecoregion from 1973-2001.

\begin{tabular}{cccc}
\hline Rank & From Class & To Class & Area Changed $\left(\mathbf{k m}{ }^{2}\right)$ \\
\hline 1 & Nonmech. Disturbed & Grass/Shrubland & 470 \\
2 & Grass/Shrubland & Nonmech. Disturbed & 382 \\
3 & Forest & Nonmech. Disturbed & 119 \\
4 & Grass/Shrubland & Developed & 104 \\
5 & Grass/Shrubland & Forest & 102 \\
6 & Nonmech. Disturbed & Forest & 60 \\
7 & Grass/Shrubland & Water & 27 \\
8 & Agriculture & Developed & 22 \\
10 & Mech. Disturbed & Grass/Shrubland & 21 \\
11 & Nonmech. Disturbed & Nonmech. Disturbed & 21 \\
& Forest & Developed & 16 \\
\hline
\end{tabular}

Mech., mechanically; Nonmech., nonmechanically] 
Table 3. Average annual gains and losses by land-use/land-cover class for the Southern California Mountains ecoregion.

\begin{tabular}{|c|c|c|c|c|c|}
\hline $\begin{array}{l}\text { Normalized Gains and Losses } \\
\text { (km²/year) }\end{array}$ & 1973 & 1980 & 1985 & 1992 & 2001 \\
\hline \multicolumn{6}{|l|}{ Water } \\
\hline Losses & - & - & -1.6 & -3.1 & -0.2 \\
\hline Gains & - & 4.5 & - & 0.2 & 0.6 \\
\hline Net change (gains minus losses) & - & 4.5 & -1.6 & -2.9 & 0.5 \\
\hline \multicolumn{6}{|l|}{ Developed } \\
\hline Gains & - & 5.9 & 7.2 & 6.2 & 6.2 \\
\hline \multicolumn{6}{|l|}{ Mechanically disturbed } \\
\hline Losses & - & -3.7 & -0.6 & -0.5 & -0.6 \\
\hline Gains & - & 0.4 & 1.3 & 1.7 & 0.8 \\
\hline Net change (gains minus losses) & - & -3.3 & 0.7 & 1.1 & 0.2 \\
\hline \multicolumn{6}{|l|}{ Nonmechanically disturbed } \\
\hline Losses & - & -21.7 & -9.7 & -38.1 & -7.3 \\
\hline Gains & - & 4.5 & 53.9 & 9.1 & 15.4 \\
\hline Net change (gains minus losses) & - & -17.2 & 44.1 & -29.0 & 8.1 \\
\hline \multicolumn{6}{|l|}{ Forest } \\
\hline Losses & - & -0.7 & -23.1 & -0.7 & -1.6 \\
\hline Gains & - & 8.0 & 0.2 & 0.8 & 11.1 \\
\hline Net change (gains minus losses) & - & 7.3 & -22.9 & 0.1 & 9.4 \\
\hline \multicolumn{6}{|l|}{ Grass/Shrubland } \\
\hline Losses & - & -13.6 & -38.8 & -14.1 & -28.2 \\
\hline Gains & - & 16.7 & 10.7 & 39.3 & 7.3 \\
\hline Net change (gains minus losses) & - & 3.1 & -28.1 & 25.2 & -20.9 \\
\hline \multicolumn{6}{|l|}{ Agriculture } \\
\hline Losses & - & -1.6 & -0.7 & -1.5 & -0.4 \\
\hline Gains & - & 0.9 & 1.1 & 0.3 & 0.2 \\
\hline Net change (gains minus losses) & - & -0.7 & 0.3 & -1.2 & -0.2 \\
\hline \multicolumn{6}{|l|}{ Mining } \\
\hline Losses & - & - & - & - & - \\
\hline Gains & - & 0.3 & 0.2 & 0.4 & 0.2 \\
\hline Net change (gains minus losses) & - & 0.3 & 0.2 & 0.4 & 0.2 \\
\hline \multicolumn{6}{|l|}{ Wetland } \\
\hline Losses & - & - & - & - & -0.1 \\
\hline Gains & - & - & 0.1 & 0.1 & - \\
\hline Net change (gains minus losses) & - & - & 0.1 & 0.1 & -0.1 \\
\hline
\end{tabular}


Table 4. Rates of land-use/land-cover changes grouped according to the processes that the changes represent.

\begin{tabular}{|c|c|c|c|c|c|c|}
\hline $\begin{array}{l}\text { Land-use/land-cover class } \\
\text { From class }\end{array}$ & To class & $\begin{array}{c}1973-1980 \\
\text { km²/yr }\end{array}$ & $\begin{array}{c}1980-1985 \\
\mathrm{~km}^{2} / \mathrm{yr}\end{array}$ & $\begin{array}{c}1985-1992 \\
\text { km²/yr }\end{array}$ & $\begin{array}{c}1992-2001 \\
\mathrm{~km}^{2} / \mathrm{yr}\end{array}$ & $\begin{array}{r}1973-200 \\
\mathrm{~km}^{2} / \mathrm{yr}\end{array}$ \\
\hline \multicolumn{7}{|l|}{ Fire } \\
\hline Forest & Nonmech. disturbed & $<1$ & 20.7 & $<1$ & 1.6 & 4.3 \\
\hline Grass/Shrubland & Nonmech. disturbed & 4.4 & 33.2 & 8.9 & 13.6 & 13.6 \\
\hline Nonmech. disturbed & Nonmech. disturbed & 2.5 & - & $<1$ & $<1$ & $<1$ \\
\hline \multirow[t]{2}{*}{ Agriculture } & Nonmech. disturbed & - & - & - & $<1$ & $<1$ \\
\hline & Total & 7.0 & 53.9 & 9.5 & 15.4 & 18.7 \\
\hline \multicolumn{7}{|l|}{ Regeneration (from fire) } \\
\hline Nonmech. disturbed & Grass/Shrubland & 13.9 & 9.5 & 37.3 & 7.1 & 16.8 \\
\hline Nonmech. disturbed & Forest & 7.5 & $<1$ & $<1$ & $<1$ & 2.2 \\
\hline Nonmech. disturbed & Developed & $<1$ & - & - & - & - \\
\hline Nonmech. disturbed & Total & 21.6 & 9.7 & 38.1 & 7.2 & 19.0 \\
\hline
\end{tabular}

Regeneration (intermediate)

Grass/Shrubland

Forest

$<1$

10.5

3.6

[Dashes (-) are used to show rates that equal zero $\mathrm{km}^{2} / \mathrm{yr}$ in order to highlight rates greater than zero. Nonmech., nonmechanically]

Table 5. Gross change and corresponding margin of error for each time period for the Southern California Mountains ecoregion.

\begin{tabular}{lcc}
\hline Period & Gross Change $\%$ & $\begin{array}{c}\text { Margin of Error } \\
85 \% \\
\text { Confidence Interval }\end{array}$ \\
\hline 1973 to 1980 & $1.6 \%$ & $+/-1.0 \%$ \\
1980 to 1985 & $2.1 \%$ & $+/-1.5 \%$ \\
1985 to 1992 & $2.3 \%$ & $+/-1.6 \%$ \\
1992 to 2001 & $1.9 \%$ & $+/-1.1 \%$ \\
\hline
\end{tabular}

